\title{
Intragenic antimicrobial peptides from Theobroma cacao
}

\author{
Marcelo Ramada ${ }^{1 *}$, Guilherme Brand ${ }^{1}$, Fernando Abrão ${ }^{2}$, Lucia Souza ${ }^{2}$, Maria Silva ${ }^{2}$, Carlos Bloch Jr \\ From 5th Congress of the Brazilian Biotechnology Society (SBBIOTEC) \\ Florianópolis, Brazil. 10-14 November 2013
}

\begin{abstract}
Background
It is well known that many bioactive peptides (intragenic) are encrypted in source proteins and that they can exert their function once released by proteolytic cleavage; e.g. hypotensive, opioids and antimicrobial peptides. However, other bioactive peptides may be "stuck" on a polipeptide chain with no cleavage sites for its release. These "non-obvious" intragenic peptides are also of interest in the search for new biologically active peptides, mainly antimicrobial peptides, in an alternative way for new drug discovery and for the control of different phytopathogens, mainly fungi, that can cause several losses to different crops of interest; e.g. rice, soybean, common bean, cocoa. In Brazil, Theobroma cacao production can be decimate by the basidiomycete Moniliophtora perniciosa, the causative agent of cocoa witch's broom disease. In this report we present preliminary results of the search, synthesis and activity of intragenic antimicrobial peptides (IAPs) selected from Theobroma cacao genome.
\end{abstract}

\section{Methods}

In this study, we performed a search of putative IAPs using Theobroma cacao Matina 1.6 genome [1]. Search was performed using the software Kamal v1.0 alpha [2] with usercreated parameters. Eleven peptides out of 700000 filtered peptides were selected for in-house solid-phase synthesis. DS01 [3] and Ascaphin-8 [4] were also synthesized as positive controls. Peptides were purified by RP-HPLC in a preparative $\mathrm{C} 18$ column. The purity and molecular mass of peptides were evaluated by MALDI-TOF MS (UltraFlex III, Bruker Daltonics). Peptide fragmentation was obtained by MALDI-TOF MS/MS experiments and the resulting data were analyzed manually using Flex Analysis 3.0

'EMBRAPA Recursos Genéticos e Biotecnologia - Parque Estação Biológica, 70770-917, Brasília-DF, Brazil

Full list of author information is available at the end of the article
(Bruker Daltonics) software to confirm synthetic peptides aminoacid sequence. The minimum inhibitory concentrations (MIC) of the synthetic peptides for Candida albicans ATCC 90028 and Cryptococcus neoformans ATCC 28957 was determined by microdilution broth method, according to CLSI M27-3a document [5] and were evaluated at concentrations between $256 \mu \mathrm{M}-0.5 \mu \mathrm{M}$.

\section{Results and conclusions}

Pep2, Pep5, Pep6, Pep8 and Pep10 showed MICs against C. neoformans ATCC and C. albicans ATCC. The data obtained for DS01 and Ascaphin-8 for C. albicans showed MICs of 6 and $8 \mu \mathrm{M}$, respectively, in agreement with the literature [3,4]. Pep5 and Pep10 showed MICs of 128 and $64 \mu \mathrm{M}$, respectively. Pep6 and Pep8 inhibit C. albicans and $C$. neoformans growth at $4 \mu \mathrm{M}$ and $8 \mu \mathrm{M}$. Pep2 was able to inhibit and kill both fungi at $2 \mu \mathrm{M}$. Pep2, 6 and 8 showed lower MIC values than DS01 and Ascaphin-8 for C. neoformans. Synthetic peptides 2, 6 and 8 showed promising results against human pathogenic fungi highlighting the importance of this approach to search for new drugs. To evaluate if this approach can render promising results for agriculture, which is the main goal of our study, MICs assays are being performed with some fungi phytopathogens. This approach can be use as an alternative to the transgenic technology as the plant own information, not an exogenous one, could be used for the control of phytopathogens, as proposed for soybean [2].

\section{Acknowledgements \\ CNPq, Embrapa, UnB and UFG.}

\section{Authors' details}

'EMBRAPA Recursos Genéticos e Biotecnologia - Parque Estação Biológica, 70770-917, Brasília-DF, Brazil. nstituto de Patologia Tropical e Saúde Pública (IPTSP), Universidade Federal de Goiás, 74605-050, Goiânia-GO, Brazil.

Published: 1 October 2014 


\section{References}

1. Cacao Genome Database. [http://www.cacaogenomedb.org].

2. Brand GD, Magalhães MTQ, Tinoco MLP, Aragão FJL, Nicoli J, Kelly SM, Cooper A, Bloch Jr. C: Probing Protein Sequences as Sources for Encrypted Antimicrobial Peptides. PLoS One 2012, 7(9):e45848.

3. Brand GD, Leite JRSA, Silva LP, Albuquerque S, Prates MV, Azevedo RB, Carregaro V, Silva JS, Sá VCL, Brandão RA, Bloch C Jr: Dermaseptins from Phyllomedusa oreades and Phyllomedusa distincta. J Biol Chem 2002, 277(55):49332-49340.

4. Conlon JM, Sonnevend A, Davidson C, Smith DD, Nielsen PF: The ascaphins: a family of antimicrobial peptides from the skin secretions of the most primitive extant frog, Ascaphus truei. Biochem Biophys Res Commun 2004, 320(1):170-175.

5. CLSI. Reference Method for Broth Dilution Antifungal Susceptibility Testing of Yeasts. 3rd edn edition. Wayne, PA: Clinical and Laboratory Standards Institute; 2008, Approved Standard M27- A3.

doi:10.1186/1753-6561-8-S4-P106

Cite this article as: Ramada et al.: Intragenic antimicrobial peptides from Theobroma cacao. BMC Proceedings 2014 8(Suppl 4):P106.

\section{Submit your next manuscript to BioMed Central} and take full advantage of:

- Convenient online submission

- Thorough peer review

- No space constraints or color figure charges

- Immediate publication on acceptance

- Inclusion in PubMed, CAS, Scopus and Google Scholar

- Research which is freely available for redistribution

Submit your manuscript at www.biomedcentral.com/submit 